\title{
A Normative Case for Abolishing the Doctrine of Extended Joint Criminal Enterprise
}

\author{
Bo Wang \\ (School of Law, University of Surrey)
}

\begin{abstract}
It is submitted in this article that assisting/encouraging is normatively different from and less harmful and dangerous than perpetration, and that the unfairness and injustice of complicity is doubled in the context of extended joint criminal enterprise. The defendant's participation in the underlying crime is constructed as participation in the collateral crime and such fictitiously constructed participation is further constructed as actus reus of the collateral crime; and the defendant's foresight of the collateral crime is constructed as intention to assist/encourage the collateral crime and such fictitiously constructed mental state is further constructed as sufficient mens rea for the collateral crime. The double constructive nature of this doctrine cries out for legal reform, especially in jurisdictions where it is still retained as a sui generis doctrine. It is proposed that a new lesser offence of risking another's collateral offending will serve better the purpose of fair labelling and proportionate punishment.
\end{abstract}

Key Words: Extended joint criminal enterprise; constructive liability; change of normative position; fair labelling; proportionate punishment; risk-taking

\section{Introduction}

The common law doctrine that a person could be liable for a collateral crime B committed by his or her confederate if he or she shared a common purpose with that person to do crime A foreseeing that crime B might be committed in the course of doing crime $\mathrm{A}$ is under intensive 
debate in recent years. This doctrine is termed as "joint enterprise complicity" ${ }^{1}$ or "parasitic accessorial liability' ${ }^{2}$ in England and Wales and 'extended joint criminal enterprise' in Australia $^{3}$ and Hong Kong. ${ }^{4}$ Under this doctrine there is no need to prove that $\mathrm{D}$ had provided actual assistance or encouragement to the commission of the collateral crime by $\mathrm{P}$. It was held that D's liability for the collateral crime hinged on his or her participation in the underlying crime with a foresight that the collateral crime might be committed by $\mathrm{P}$ in the course of doing the underlying crime. ${ }^{5}$ Such a doctrine could be said to have gained its life after Chan Wing-Siu v The Queen —a 1985 decision of the Privy Council. ${ }^{6}$ This case was then followed by $R v$ Powell and English ${ }^{7}$ in England and Wales as a leading case for joint enterprise complicity, which had been applied thereafter until it has been abolished by the recent case of $R v$ Jogee. ${ }^{8}$ Now, it is the law in England and Wales that for an accessory to be liable for the offences committed by the perpetrator it has to be proved that the accessory has actually assisted or encouraged the perpetrator intending to assist/encourage the perpetrator to commit the target crime; and foresight that $\mathrm{P}$ might commit the crime is not sufficient to make D liable for that crime. ${ }^{9}$ This reinterpretation of the law of complicity receives support $^{10}$ as well as challenges. ${ }^{11}$

\footnotetext{
${ }^{1} R$ v ABCD [2011] QB 841; $R$ v Rahman [2008] 3 WLR 264; Beatrice Krebs, "Joint Criminal Enterprise" (2010) 73(4) Modern Law Review 578, 592; A. P. Simester, “The Mental Element in Complicity” (2006) 122 (4) Law Quarterly Review 578, 585-586; House of Commons, Justice Committee, Joint Enterprise, Eleventh Report of Session 2010-12, 16, Jeremy Horder's response to (Q108).

${ }^{2}$ R. v Gnango [2012]1 AC 827; J. C. Smith, "Criminal Liability of Accessories: Law and Law Reform” (1997) 113 Law Quarterly Review 453, 465.

${ }^{3}$ McAuliffe v The Queen [1995] 183 CLR 108; Clayton v The Queen [2006] 168 A Crim R 174.

${ }^{4}$ Chan Wing-Siu v The Queen [1985] AC 168; Sze Kwan-Lung v HKSAR [2004] 7 HKAFCR 475.

${ }^{5} R v$ Powell and English [1999]1 AC 1, at 2; $R v A B C D$ [2011] QB 845, 849.

${ }^{6}[1985]$ AC 168 .

${ }^{7}[1999] 1$ AC 1.

${ }^{8}$ [2016] UKSC 8.

${ }^{9} R v$ Jogee [2016] UKSC 8 at [9].

${ }^{10}$ Matthew Dyson, "Shorn-off complicity" (2016) 75 (2) Cambridge Law Journal 196, 199; D. J. Baker, "Lesser Included Offences, Alternative Offences and Accessorial Liability" (2016) 80 (6) Journal of Criminal Law 446, 449.
} 
The High Court of Australia in its recently decided case Miller $v$ The Queen ${ }^{12}$ rejected to follow $R v$ Jogee holding that all parties to a joint criminal enterprise should be liable for any collateral crime committed by a co-venturer that is within the scope of their agreement and that an incidental crime contemplated by the parties is within the scope of the agreement. ${ }^{13}$ The most recent Hong Kong case involving joint enterprise complicity is HKSAR $v$ Chan Kam-Shing, ${ }^{14}$ which reiterated that joint enterprise complicity is distinct from standard complicity of assisting/encouraging, ${ }^{15}$ and that Chan Wing-Siu should be followed in Hong Kong. The law governs joint enterprise complicity is no longer common. ${ }^{16}$ The divergence among these three influential cases is whether Chan Wing-Siu v The Queen has set the correct mens rea element to make a participant in a joint criminal enterprise liable for any collateral crime committed. Likewise, many scholarly works have focused on the mens rea part of complicity liability providing us very illuminating ideas about whether the law is well principled. ${ }^{17}$ However, this paper will provide a different perspective looking into the double constructive nature of extended joint criminal enterprise liability, which will cover both the actus reus and mens rea aspects.

\footnotetext{
${ }^{11}$ A. P. Simester, “Accessory Liability and Common Unlawful Purposes” (2017) 133 Law Quarterly Review 73, 86; D. J. Baker, "Jogee: Jury Directions and the Manslaughter Alternative" (2017) 1 Criminal Law Review 51, 54; David Ormerod and Karl Laird, "Jogee: Not the End of a Legal Saga but the Start of One?”(2016) 8 Criminal Law Review 539, 543; Findlay Stark, "The Demise of 'Parasitic Accessorial Liability': Substantive Judicial Reform, not Common Law Housekeeping" (2016) 75 (3) Cambridge Law Journal 550, 578-579.

12 [2016] HCA 30.

${ }^{13}$ Miller v The Queen [2016] HCA 30 at [4].

14 [2016] HKEC 2715.

${ }^{15}$ HKSAR v Chan Kam-Shing [2016] HKEC 2715 at [33]-[40].

${ }^{16}$ Simester, n. 11 above, 73.

${ }^{17}$ Simester, n.11 above; Dyson, n. 10 above; Baker, n. 11 above; Graham Virgo, "Joint Enterprise Liability is Dead: Long Live Accessorial Liability" (2012) 11 Crimal Law Review 850; G. R. Sullivan, "Doing Without Complicity” (2012) Journal of Commonwealth Criminal Law 199; William Wilson and David Ormerod, "Simply Harsh to Fairly Simple: Joint Enterprise Reform" (2015) 1 Criminal Law Review 3; Simester, n.1 above; Joshua Dressler, "Reassessing the Theoretical Underpinnings of Accomplice Liability: New Solutions to an Old Problem" (1985) 37(1) The Hastings Law Journal 91.
} 


\section{The Common Law Doctrine of Extended Joint Criminal Enterprise}

The term "joint enterprise" can be used to refer to "three related but not identical situations" 18 where two or more people agree to commit an offence or share with each other an intention to commit an offence. The first situation refers to the case where all participants act in concert as co-perpetrators to commit a single crime and the crime is subsequently committed. This is a straightforward case of perpetration and it has nothing to do with complicity. The second situation involves the case where $\mathrm{D}$ and $\mathrm{P}$ have a common purpose to commit a single crime with $\mathrm{D}$ being the assister/encourager and $\mathrm{P}$ being the perpetrator and the crime is subsequently committed by $\mathrm{P}$. This is a standard case of complicity, and $\mathrm{P}$ will be liable for the crime as a perpetrator while $\mathrm{D}$ will be liable for the crime as an accessory. The third situation is the one that attracts special attention from scholars and commentators. ${ }^{19}$ It covers the case where two persons act in concert to commit a crime A, over which they all share a common purpose, and in the course of it one of them has committed crime B which the other person has foreseen as a possible incident. The first two situations could be deemed as standard case of joint enterprise, or "plain vanilla" joint enterprise according to Professor Simester. ${ }^{20}$ The third situation is the target of this paper, i.e. extended joint criminal enterprise.

\footnotetext{
${ }^{18} R \vee A B C D$ [2011] QB 841, 845.

${ }^{19}$ Simester, n.1 above, 592; A. P. Simester et al, Criminal Law: Theory and Doctrine (Oxford: Hart Publishing, 5th ed, 2013) 245; See D. J. Baker, Foresight in Common Purpose Complicity/Joint Enterprise Complicity: It Is a Maxim of Evidence, Not a Substantive Fault Element (Draft Chapter(2013/14): Reinterpreting Criminal Complicity, forthcoming) (October 10, 2012) Social Science Research Network <http://ssrn.com/abstract=2507529>, at 38, accessed on 10 October, 2012 .

${ }^{20}$ Simester, n. 11 above, 76 .
} 
The rule regarding joint enterprise cases in English criminal law can be traced at least as far back as Lord Dacre's case, ${ }^{21}$ where Lord Dacre and some others agreed to steal deer in a park with one of the participants in the theft of the deer killing a gamekeeper. Lord Dacre was on the other side of the park but they were all held liable for murder, ${ }^{22}$ because they were acting in concert and were impliedly encouraging each other to use whatever force was necessary to avoid arrest. It can be said that the collateral crime is authorised impliedly by those participants in the enterprise and therefore it was a plain vanilla case of joint enterprise. Sir Matthew Hale wrote that if several persons come to commit an unlawful act and were present at the time of the act, they will all be liable for that crime though only one of them did it. ${ }^{23}$ The same dictum was adopted by Sir Michael Foster in his Crown Cases: ${ }^{24}$

\begin{abstract}
So that if several persons set out together, or in small parties, upon one common design, be it murder or other felony, or for any other purpose unlawful in itself, ... they are all, provided the fact be committed, in the eye of the law [equally liable]; ... for it was made a common cause with them, each man operated his station at one and the same instant, towards the same common end, and the part each man took tended to give countenance, encouragement, and protection to the whole gang, and to insure the success of their common enterprise.
\end{abstract}

The standard case of joint enterprise faces few challenges because it goes through the route either of co-perpetration or standard complicity of assisting or encouraging. If all participants have committed the actus reus of the crime with required mens rea then they should all be liable for the crime as perpetrators. If only one of them has committed the crime, the rest of them have given encouragement by agreeing that the crime should be committed and therefore should be liable as accessories. It is a logical conclusion by applying the "plain

\footnotetext{
${ }^{21}$ Lord Dacre's Case (1535) 72 Eng Rep 458 (KB).

${ }^{22}$ Matthew Hale, The History of the Pleas of the Crown Vol. 1 (London: Professional Books, 1678) 215.

${ }^{23}$ Ibid, 443-444.

${ }^{24}$ Michael Foster, Crown Cases (Oxford: Clarendon Press, 1776) 354.
} 
vanilla" joint enterprise that if participants only had a common purpose to steal, and the collateral crime of one of them was merely the result of the situation in which he found himself, without any previous agreement, then the rest should not be liable for this collateral offence. $^{25}$

The key question is what is included in the common purpose. If $\mathrm{D}$ and $\mathrm{P}$ have a common purpose to do crime $\mathrm{A}$ and in the course of it $\mathrm{P}$ has committed crime $\mathrm{B}$, under what circumstances can it be said that crime B is included in the common purpose as well? In the $19^{\text {th }}$ century case of $R v$ Cramp, it was held that 'a person is an accomplice in the crime charged if he took part in its commission, and was privy to the criminal intent of the thing done. ${ }^{26}$ According to such reasoning, a person who participated in a joint enterprise of doing crime A knowing or contemplating the incidental crime $\mathrm{B}$, will be deemed as providing encouragement not only for crime A but also for crime B. Subsequent cases used terms such as "within the scope of the joint enterprise" 27 and "within the ambit of the common agreement" ${ }^{28}$ to decide whether D should be liable for P's collateral offence in the course of executing the underlying crime of their joint enterprise. ${ }^{29}$ At this stage terms like "contemplation" and "foresight" started to emerge in judgments. In Davies $v$ DPP, it was held: ${ }^{30}$

\footnotetext{
${ }^{25} R v$ Collison (1831) 4 Car \& P 565, 828.

${ }^{26} R v$ Cramp (1880) 14 Cox CC 390, 393.

${ }^{27} R v$ Radalyski (1899)24 VLR 687; $R v$ Murray [1924] VLR 374; $R v$ Surridge [1942] 42 SR (NSW) 278; $R v$ Smith [1963] 1 WLR 1200; $R v$ Vandine [1970] 1 NSWR 252; Johns v The Queen [1980] 143 CLR 108; $R v$ Lovesey [1970]1 QB 352.

${ }^{28} R v$ Anderson and Morris [1966] 2 QB 110; $R v$ McClafferty [1980] 11 NIJB; $R v$ Dunbar [1988] Crim LR 693.

${ }^{29}$ See Sir Roger Tulson, "Sir Michael Foster, Professor Williams and Complicity in Murder" in Dennis J. Baker and Jeremy Horder (eds), The Sanctity of Life and the Criminal Law--The Legacy of Glanville Williams (Cambridge: Cambridge University Press, 2013) 230, 236.

${ }^{30}$ Davies v DPP [1954] AC 378, 401, per Lord Simonds and Lord Chancellor.
} 
In particular, I can see no reason why, if half a dozen boys fight another crowd, and one of them produces a knife and stabs one of the opponents to death, all the rest of his group should be treated as accomplices in the use of a knife and the infliction of mortal injury by that means, unless there is evidence that the rest intended or concerted or at least contemplated an attack with a knife by one of their number, as opposed to a common assault." [My emphasis]

The Court in this judgment made contemplation an alternative to intention. The law tended to divert from the route of common purpose to another route of foresight. At first, it seems to require that any collateral crime committed has to be within the common purpose, which means there is a tacit agreement or conditional common intention among participants over the collateral crime. And gradually it was asserted that a collateral crime falls within the common purpose if it is within the contemplation of participants or if it is foreseen as a possible incident of the execution of their joint criminal enterprise. ${ }^{31}$ The fact that $\mathrm{D}$ has foreseen or contemplated the collateral crime works as evidence from which a jury can conclude that the collateral crime is within the common purpose. Finally, foresight was made a sufficient fault element to make participants fully liable as perpetrators for the collateral crime in Chan Wing-Siuv The Queen. ${ }^{32}$ The Privy Council observed that the joint enterprise case must depend rather on the wider principle whereby D is criminally liable for acts done by $\mathrm{P}$ of a type which the former foresees but does not necessarily intend. ${ }^{33}$ It is not my intention to examine whether Sir Robin Cooke in this case had misinterpreted the doctrine of joint enterprise. ${ }^{34}$ However, the objective effect of this case is that $\mathrm{D}$ will be made fully liable for the collateral crime committed in the course of their joint enterprise to do the underlying

\footnotetext{
${ }^{31}$ Johns $v$ The Queen [1980] 143 CLR 108, 131; R v Smith [1963] 1 WLR 1200, 1200.

${ }^{32}$ Chan Wing-Siu v The Queen [1985] AC 168.

${ }^{33}$ Ibid, 175.

${ }^{34}$ There are arguments about whether Chan Wing-Siu v The Queen took a wrong turn. See Simester, n. 11 above, 81; D. J.

Baker, 'Reinterpreting the Mental Element in Criminal Complicity: Change of Normative Position Theory Cannot Rationalize the Current Law,' (2016) 40 Law and Psychology Review 121, 221.
} 
crime as long as the collateral crime is foreseen by D and no common purpose or shared intention is required on the part of $\mathrm{D}$ with regard to the collateral crime. This extended joint criminal enterprise liability is distinct from the "plain vanilla" joint enterprise in that it does not require common intention. This form of liability is distinct from standard complicity as well in that it does not require actual assistance or encouragement given to the collateral crime and that D's participation in the underlying crime with a foresight of the collateral crime is sufficient to make him or her fully liable as a perpetrator for that crime. ${ }^{35}$ The wrong in standard complicity is grounded on D's contribution to the target crime while the wrong in extended joint criminal enterprise lies in the mutual embarkation on the underlying crime being aware that the collateral crime might be committed. ${ }^{36}$

English courts however take this extended joint criminal enterprise liability as an aspect of complicity $^{37}$ asserting that by joining in the underlying crime, the participant has lent himself to the enterprise and by so doing has assisted or encouraged the perpetrator in the collateral offending. It was held that once a common purpose to commit the underlying crime is proved there is no need to look for further evidence of assisting or encouraging. ${ }^{38}$ However, this assertion is based on a legal fiction that by agreeing to do crime $\mathrm{X}$ the defendant, ipso facto, assists or encourages crime Y. ${ }^{39}$ But this is not always the case. Joining in an enterprise of robbery does not always mean D agrees that murder should be committed as well. For example, it is D's first offending and D has never thought about implicating himself in the

\footnotetext{
${ }^{35}$ HKSAR v Chan Kam-Shing [2016] HKEC 2715 at [33]; Sze Kwan Lung v HKSAR [2004] 7 HKCFAR 475; Miller v The Queen [2016] HCA 30 at [4]; See Simester n.1 above, 592; Jeremy Horder's response to (Q108), n.1 above; see also Krebs, n. 1 above, 592.

${ }^{36}$ Clayton v The Queen [2006]168 A Crim R 174, 179.

${ }^{37} R \vee A B C D$ [2011] QB 841, 854. Professor Smith also argues there is only one doctrine of complicity. Smith, n. 2 above, 465. See also David Ormerod and Karl Laird, Smith and Hogan's Criminal Law (Oxford: Oxford University Press, $14^{\text {th }}$ ed, 2015) 238.

${ }^{38} R v$ Mendez [2011] QB 876, 882.

${ }^{39}$ Simester, n.1 above, 585-586.
} 
most serious offence of murder. Furthermore, in some cases, D has expressed his or her dissent in using any violence and therefore it can hardly be said that, by joining the underlying offence, D has actually provided assistance or encouragement to the collateral offending of which D strongly disapproves.

It is submitted, with the support of a number of scholars, ${ }^{40}$ that extended joint criminal enterprise liability is distinct from standard complicity because under extended joint criminal enterprise liability it is not necessary to prove that $\mathrm{P}$ is actually assisted or encouraged by D's conduct with regard to the collateral crime, ${ }^{41}$ neither is it necessary to show that $\mathrm{D}$ intends to do an act of assisting or encouraging. It is also submitted that the defendant's full liability for the collateral crime has a double constructive nature. Take the typical robbery/murder case for instance, a participant in an enterprise of robbery would be made fully liable for murder in the same way as the perpetrator of murder if he or she foresaw as a possibility that $\mathrm{P}$ might kill someone in the course of the robbery even if he or she had expressed his or her dissent to any killing. On the one hand, D's participation in robbery is constructed as assisting or encouraging the collateral crime of murder and such constructed assistance or encouragement is further constructed as actus reus of murder (unlawful killing of a human being). On the other hand, D's mere foresight of the commission of murder is constructed as sufficient mens rea for standard complicity (an intention to assist/encourage knowing or foreseeing the essential matters of murder) and such constructive mens rea sufficient for standard complicity is further constructed as sufficient mens rea for murder (an intention to kill or cause grievous bodily harm). A person, under extended joint criminal enterprise liability, is made fully liable for the collateral crime when he or she has not even assisted or encouraged

\footnotetext{
40 AP Simester, et al., Simester and Sullivan's Criminal Law: Theory and Doctrine (4th ed Hart Publishing, Oxford 2010) 243;. See also Krebs, n. 1 above, 592; Janice Brabyn, "Secondary Party Criminal Liability in Hong Kong" (2010) 40 Hong Kong Law Journal 623, 625.

${ }^{41}$ Sullivan, n. 17 above, 209.
} 
its commission, nor has he or she ever intended its commission. Such double constructive liability fails to reflect correctly the harm-doing and personal culpability of the individual who merely risks the collateral crime by joining in the underlying crime.

\section{Attempts Made to Justify Extended Joint Criminal Enterprise Doctrine}

Extended joint criminal enterprise liability is an extension to standard complicity making a participant fully liable as a perpetrator for the collateral crime which falls outside their common purpose, and therefore it need be justified. We have seen several attempts made tying to justify extended joint criminal enterprise liability as a mechanism to make a participant fully liable for the collateral crime, namely the change of normative position theory, ${ }^{42}$ the association theory ${ }^{43}$ and pragmatic and policy reasons. ${ }^{44}$ However, none of them gives convincing justification for extended joint criminal enterprise liability.

The change of normative position theory is normally invoked to justify a strict liability element in a crime. Professor Gardner is the most erudite scholar to be seduced by the change of normative position theory. Gardner states that by committing assault a person changes his normative position and therefore certain adverse consequences and circumstances, which would not count against him but for his original assault, now count against him

\footnotetext{
${ }^{42}$ Andrew Ashworth, "A Change of Normative Position: Determining the Contours of Culpability in Criminal Law" (2008) 11(2) New Criminal Law Review 232; Youngjae Lee, "Recidivism As Omission: A Relational Account" (2009) 87(3) Texas Law Review 571.

${ }^{43}$ Virgo, n. 17 above, 856.

${ }^{44}$ Clayton v The Queen [2006] 168 A Crim R 174, 206 at [79]; Powell and English [1999] 1 AC 1, 12.
} 
automatically. ${ }^{45}$ Arguments for dispensing with a strict proportionality principle are premised on the view that a culpable wrongdoer may have forfeited an entitlement to punishment that is proportionate to his or her past harm-doing and personal culpability, ${ }^{46}$ because he or she has changed his or her "normative position" ${ }^{47}$ Professor Horder argues: "The fact that I deliberately wrong $\mathrm{V}$ arguably changes my normative position vis a vis the risk of adverse consequences of that wrongdoing to $\mathrm{V}$, whether or not foreseen or reasonably foreseeable." 48 In the context of extended joint criminal enterprise liability, professor Simester has argued: ${ }^{49}$

Through entering into a joint enterprise, $\mathrm{S}$ changes her normative position. She becomes, by her deliberate choice, a participant in a group action to commit a crime. Moreover, her new status has moral significance: she associates herself with the conduct of the other members of the group in a way that the mere aider or abettor, who remains an independent character throughout the episode, does not.

Professors Horder and Hughes also adopt Professor Simester's justification for extended joint criminal enterprise liability. ${ }^{50}$ Change of normative position theory has strong opponents. The leading opponents are Professors Ashworth, ${ }^{51}$ Baker $^{52}$ and Mitchell. ${ }^{53}$ Plausible though it looks, the change of normative position theory stays far from being a satisfactory one in

\footnotetext{
${ }^{45}$ See John Gardner, "Rationality and the Rule of the Law in Offences against the Person" (1994) 53 Cambridge Law Journal 502, 509.

${ }^{46}$ Compare Enmund v Florida [1982] 458 US 782, 800; Mullaney v Wilbur [1975] 421 US 684, 698.

${ }^{47}$ See K. W. Simons, "Is Strict Criminal Liability in the Grading of Offences Consistent with Retributive Desert?" (2012) 32(3) Oxford Journal of Legal Studies 445; William Wilson, "Murder and the Structure of Homicide" in Andrew Ashworth and Barry Mitchell (eds), Rethinking English Homicide Law (Oxford: Oxford University Press, 2000) 40.

${ }^{48}$ Jeremy Horder, "A Critique of the Correspondence Principle in Criminal Law" (1995) Crim. L.R . 759, 764.

${ }^{49}$ Simester, n. 1 above, 598-599.

${ }^{50}$ Jeremy Horder and David Hughes, "Joint Criminal Ventures and Murder: The prospect for Law Reform" (2009) 20(3) King's Law Journal 379, 398.

${ }^{51}$ Andrew Ashworth, Positive Obligations in Criminal Law (Oxford: Hart Publishing, 2013) 130-147.

${ }^{52}$ Baker, n. 19 above, 82.

${ }^{53}$ Barry Mitchell, "Minding the Gap in Unlawful and Dangerous Act Manslaughter: A Moral Defence for One-punch Killers" (2008) 72(6) Journal of Criminal Law 537, 541-542.
} 
justifying a person's liability for the unintended consequences resulting from his commission of a crime. In the first place, it is implicit what kind of normative position it is to be changed by committing a crime. It is true that criminal law sets out an abstract general rule that we should not infringe others' interests by committing crimes; $;{ }^{54}$ so when each individual in our society acts lawfully, peace and mutual respect are guaranteed. In this sense, it could be said that a person's normative position as an innocent individual who is protected from criminal prosecution has been changed. However, criminal law, especially contemporary criminal law, is not just a simple system in deciding what is lawful and what is unlawful; it is much more than that. Criminal law takes culpability and harm as the basis for imposing criminal liability ${ }^{55}$ and has developed a sophisticated and interactive system to categorise different types of wrongs into different crimes. The normative position of an offender varies due to the crimes he has committed. The ambiguous and implicit explanation of what the exact normative position is cannot answer why a person by committing one kind of criminal wrongdoing should be responsible for a specific harmful unintended consequence ensued. We need a much clearer interpretation of what the normative position is.

In the second place, we are told that by committing a common assault on V, D had changed his normative position vis-à-vis $\mathrm{V}$ in such a way as to render $\mathrm{D}$ liable for greater harm than $\mathrm{D}$ foresaw when he was committing the assault, but we are not told why this should be so. ${ }^{56}$ Professor Ashworth observes that most defenders of change of normative position theory state it is "intentionality" that changes a person's normative position. ${ }^{57}$ However, based on the notion of intentionality it encounters problems in applying to impulsive conduct or acts

\footnotetext{
${ }^{54}$ See Ashworth, n. 42 above, 242.

${ }^{55}$ See generally Andrew von Hirsch, Censure and Sanctions (Oxford: Clarendon Press, 1993) 81.

${ }^{56}$ Ashworth, n. 42 above, 245; Horder, n. 48 above, 764.

${ }^{57}$ Ibid, Ashworth, 243.
} 
done in temper. ${ }^{58}$ Moreover, an intention to commit a specific crime does not indicate an intention to bring any harm of any description. Supporters have provided some restrictive principles to prevent it from making a person liable for consequences, which have too great a moral distance from what has been anticipated. It is asserted that entering the same family of offenses, as by committing a common assault, is said to be sufficiently morally significant to justify holding D liable for some more serious offenses against the person. ${ }^{59}$ However, we are still unclear about why the intentional or knowing commission of a crime of the same family should render a person criminally liable for the unforeseen consequences of the conduct, which might otherwise be described as accidental. As Professor Simons points out, "it is empirically absurd and normatively unacceptable to interpret every decision to commit a serious crime as an intentional waiver of the right to proportional treatment." ${ }^{90}$ It would be unjustifiable to say the defendant has forfeited all his or she rights to fair labelling and proportionate punishment to any consequences that follow from his or her conduct just because his or her very first conduct is a crime. No good reasons have been given for why and how the normative position is changed, other than the assertion that there has been a change of normative position, and that begs the question. ${ }^{61}$

The change of normative position theory encounters more problems in the context of extended joint criminal enterprise to justify holding D liable for P's collateral offending. In perpetration liability, it is the defendant's own act that has caused the unintended consequence; but in the context of extended joint criminal enterprise, quite differently, it is

\footnotetext{
${ }^{58}$ Ibid, 244.

${ }^{59}$ See John Gardner, "On the General Part of the Criminal Law", in Antony Duff (ed), Philosophy and the Criminal Law: Principle and Critique (Cambridge: Cambridge University Press, 1998) 243-244. Mitchell, n. 55 above, 541; C. M. V. Clarkson, "Context and Culpability in Involuntary Manslaughter", in Jeremy Horder (ed), Rethinking English Homicide Law (Oxford, Oxford University Press, 2004) 160.

${ }^{60}$ Simons, n. 47 above, 449.

${ }^{61}$ Ashworth, n. 42 above, 245.
} 
the autonomous and independent perpetrator's deliberate voluntary action that has caused the prohibited harm in the collateral crime. There is a big moral difference between a person taking the consequences of his or her own personal acts and taking the consequences of the autonomous and independent conduct of another. ${ }^{62}$ It might be plausible to say that the defendant has changed his or her normative position with regard to the protected interest in the underlying crime he or she assisted/encouraged, but it is unjustifiable to say that such a defendant has changed his or her normative position in relation to any protected interest in any possible incidental crime which is not even the product of his or her own conduct. The change of normative position theory cannot justify making a participant in a joint criminal enterprise fully liable as a perpetrator for the collateral crime because it fails to notice the double constructive nature of extended joint criminal enterprise liability. Actually, the theory's initiator Professor Gardner has not only abandoned his original assertions, but has repudiated any suggestion that his aim was to present a positive justification for any constructive liability. ${ }^{63}$

Professor Virgo puts forward an association theory to justify extended joint criminal enterprise liability. He holds that a person should be liable for the commission of the substantive offence by another where he can be considered to be associated with it, ${ }^{64}$ and that complicity liability can be based on foresight and association. ${ }^{65}$ According to Virgo, actus reus of complicity can be based on association only; and $\mathrm{D}$, who participates in an underlying crime with the foresight that a collateral crime might be committed, can be deemed to have

\footnotetext{
${ }^{62}$ Baker, n. 19 above, 82.

${ }^{63}$ John Gardner, Offences and Defences (Oxford: Oxford University Press 2007) 246-247.

${ }^{64}$ See Virgo, n. 17 above, 860.

${ }^{65}$ Ibid, 862.
} 
associated himself with the collateral crime. ${ }^{66}$ Therefore, extended joint criminal enterprise is one aspect of complicity, not a distinct principle.

It is submitted that this association theory is indefensible in justifying extended joint criminal enterprise liability. To begin with, the argument that mere association is one form of the conduct element of complicity is never admitted by case law. Standard complicity liability requires actual assistance/encouragement though it does not matter whether the assistance/encouragement makes a difference to the commission of the target crime. ${ }^{67}$ Professor Virgo defends his assertion that association is sufficient actus reus for derivative complicity by considering the prize fight case. He states: ${ }^{68}$

\footnotetext{
Spectators at a prize fight can be considered to be accessories not simply because of their voluntary presence, but where their presence was not accidental, because they could be considered to have acted in concert with those who were fighting, so that they are associated with it, even though it cannot be proved that the fighters were actually encouraged by their presence and the fight would have occurred without their presence.
}

If there is an agreement that spectators will be present at the prize fight, it is not problematic to argue that the spectators have encouraged the fight by their presence. However, if there is no such agreement or common purpose between spectators and the fighters it is implausible to take people who are merely present at the scene as encouragers. It was held in $R v C o n e y^{69}$ that mere voluntary presence at an illegal prize fight, without any positive action, was only

\footnotetext{
${ }^{66}$ Ibid.

${ }^{67} R v$ Coney (1882) 8 QBD 534; National Coal Board $v$ Gamble [1959] 1 QB 11; $R v$ Clarkson [1971] 1 WLR 1402; $R v$ Giannetto [1997] 1 Cr App R 1; S.8 of the Accessories and Abettors Act 1861 (UK), S. 89 of the Criminal Procedure Ordinance Chap 221 (HK); Clayton v The Queen [2006] 168 A Crim R 174 at [20].

${ }^{68}$ Virgo, n. 17 above, 861.

${ }^{69} R v$ Coney (1882) 8 QBD 534.
} 
prima facie and not conclusive evidence of abetting the substantive crime. However, according to Virgo, ${ }^{70}$ knowing presence at a prize fight would be enough to hold a spectator at a prize fight, with nothing more, liable as an accessory. The court did mention the term "association" in $R v A B C D^{71}$ but the judgment should be read as a whole and in line with other leading cases as well. It was held by English courts that where D joined a criminal enterprise to do the underlying crime, his continuous participation in the enterprise, after foreseeing a collateral crime might be committed, would be regarded as assisting or encouraging the collateral crime. ${ }^{72} R v A B C D^{73}$ used association to support the argument that by associating himself or herself with the enterprise of doing the underlying crime, D was giving assistance/encouragement to the collateral crime rather than to use mere association as an independent sufficient actus reus for complicity. Therefore, the premise of professor Virgo's association theory, that association is sufficient actus reus for derivative complicity, seems to be wrong; and any arguments based on this premise are questionable.

Based on that premise, Professor Virgo argues that collateral joint enterprise liability is one aspect of derivative complicity liability, and that D's participating in the underlying crime with a foresight of the collateral crime is enough to make D fully liable as an accessory for the collateral crime as D is sufficiently associated with the collateral crime. Association with foresight could be used to infer tacit agreement or conditional intention to assist/encourage the target crime, but association itself is not sufficient as amounting to assisting/encouraging. ${ }^{74}$ There are plenty of cases where a person could associate himself

\footnotetext{
${ }^{70}$ Virgo, n. 17 above, at 861.

${ }^{71} R \cup A B C D[2011]$ QB 841.

${ }^{72} R v$ Reid [1976] 62 Cr App R 109, 112; Rv Hyde [1991] 92 Cr App R 131, 135. R v Powell and English [1999] 1 AC 1, 13; $R$ v Mendez [2011] QB 876, 882.

${ }^{73} R v A B C D$ [2011] QB 841.

${ }^{74}$ Baker, n. 19 above, 17-21.
} 
with another person's crime without assisting or encouraging. A person may harbour secret thoughts and associate himself with another's murder as he would like to see the victim get killed as well, but secret thoughts are not physical acts of encouragement or assistance. Moreover, the assertion that D's joining in the underlying crime with the foresight that a collateral crime might be committed sufficiently associates him with the collateral crime, ${ }^{75}$ is misleading. D may have agreed with $\mathrm{P}$ to commit a burglary, but that does not mean conclusively that D has associated himself with murder which is collateral to the burglary. D's foresight that murder might be committed can only be used as evidence to infer whether D has tacitly agreed or conditionally agreed that murder should be committed. ${ }^{76}$ Association theory does not tell us why mere association can equal the perpetration of the collateral crime and why mere foresight that another person might commit the collateral crime can equal the requisite mens rea of the collateral crime.

Neither the change of normative position theory nor the association theory can justify extended joint criminal enterprise liability. However, courts have taken pragmatic and policy reasons to support extended joint criminal enterprise liability. ${ }^{77}$ In the leading English case of $R v$ Powell and English, ${ }^{78}$ three main pragmatic and policy considerations were listed to justify extended joint criminal enterprise liability. Firstly, it was asserted that extended joint criminal enterprise liability is necessary for crime control because "experience has shown that joint enterprises only too readily escalate into the commission of greater offences". ${ }^{79}$ Secondly, it was contended that the doctrine of extended joint criminal enterprise relates to

\footnotetext{
${ }^{75}$ Virgo, n. 17 above, 862.

${ }^{76}$ Baker, n. 19 above, 19.

${ }^{77} R v$ Powell and English [1999] 1 AC 1, 14; Clayton v The Queen [2006] 168 A Crim R 174, 206; HKSAR v Chan KamShing [2016] HKEC 2715 at [30]; Miller v The Queen [2016] HCA 30 at [36].

${ }^{78} R v$ Powell and English [1999] 1 AC 1.

${ }^{79}$ Ibid, 14.
} 
"the need to give effective protection to the public against criminals operating in gangs". ${ }^{80}$ Thirdly, it was argued that "in the real world proof of an intention sufficient for murder would be well nigh impossible in the vast majority of joint enterprise cases." ${ }^{81}$ Such pragmatic and policy considerations have received support from scholars as well. Professors Simester and Sullivan argue that, "a group constituted by a joint unlawful enterprise is a form of society that has set itself against the law and order of society at large", ${ }^{2}$ which imports additional and special reasons why the law must intervene. However these considerations are not convincing justifications.

With regard to the first and second assertions that extended joint criminal enterprise liability serves the purpose of crime control and deterrence, I will show that the deterrence function is not as effective as English courts have alleged. Criminal law does dislike joint criminal enterprises because of their dangerousness to society; and therefore criminal law needs to take effective actions against joint criminal enterprises, especially gang activities. However, this does not mean that the only way we can deal with them is to apply double constructive liability that manifested in the extended joint criminal enterprise doctrine. A participant in a joint criminal enterprise to do a less serious underlying crime only would not be deterred from killing, since he has not killed; ${ }^{83}$ nor would such a person get his just desert for killing should he be sentenced to life imprisonment. Professor Dressler argues that "accomplice liability rules may be unjust, and not incidentally, counter-utilitarian, because-unlike all other aspects of criminal responsibility - they are not tied to the doctrine of [direct]

\footnotetext{
${ }^{80} \mathrm{Ibid}, 25$; the deterrence aim of keeping extended joint criminal enterprise liability is also expressed in House of Commons, Joint Enterprise report n. 1 above, 14.

${ }^{81} R v$ Powell and English [1999] 1 AC 1, 14.

${ }^{82}$ See Simester et al, Criminal Law: Theory and Doctrine (Oxford: Hart Publishing, 4th ed, 2010) 244.

${ }^{83}$ See Paul H. Robinson, Distributive Principles of Criminal Law: Who Should be Punished How Much (New York: Oxford University Press, 2008) chap. 8.
} 
causation." ${ }^{84}$ Posner ${ }^{85}$ and Shavell ${ }^{86}$ have argued that without any deterrent benefit, punishment is pointless. Punishing a participant in a joint enterprise for any collateral crime he foresaw as a possibility may serve the purpose of general deterrence for it gives the general public a signal that joining a joint criminal enterprise is something they should avoid. But it remains problematic to achieve such abstract general deterrence at the cost of justice and fairness by adopting a doctrine, which is incompatible with basic contemporary criminal law principles such as fair labelling and proportionate punishment. A fair and just criminal justice system can achieve the deterrence goals with the use of fair labelling and proportionate punishment. ${ }^{87}$ No extra benefit is gained from having unfair crime labels and disproportionate punishments based on double constructive liability which collateral joint enterprise liability allows for. Unjust punishments lead to disutility as far as deterrence is concerned. $^{88}$

Furthermore, it seems that punishing a participant using such double constructive liability could not achieve the goals of specific deterrence either. It is the perpetrator's autonomous and independent choice to commit the collateral crime, over which a participant in the joint enterprise has no control; therefore the cost-benefit evaluation may not work in the mind of the participant over an act which he has no control. There are many costs and benefits for those choosing to participate in a joint criminal enterprise foreseeing certain potential collateral crimes might be perpetrated by one of the participants in executing the underlying

\footnotetext{
${ }^{84}$ Dressler, n. 17 above, 93.

${ }^{85}$ Richard A. Posner, "An Economic Theory of the Criminal Law" (1985) 85(6) Columbia Law Review 1193, 1220.

${ }^{86}$ Steven Shavell, "Criminal Law and the Optimal Use of Nonmonetary Sanctions as a Deterrent" (1985) 85(6) Columbia Law Review 1232, 1256-1257.

${ }^{87}$ Clayton v The Queen [2006] 168 A Crim R 174, 217-218.

${ }^{88}$ Thomas J. Miceli and Kathleen Segerson, "Punishing the Innocent along with the Guilty: The Economics of Individual versus Group Punishment" (2007) 36(1) Journal of Legal Studies 81; Contra, Kenneth W. Simons, "Retributivists Need Not and Should Not Endorse the Subjectivist Account of Punishment" (2009) 109 Columbia Law Review Sidebar 1, 9.
} 
crime, but it is difficult to imagine any simple calculation as justifying equal liability for those participants and the perpetrators with regard to the collateral crimes. Special deterrence can only work well when those it aims to deter know the law or have a chance of guessing what the law might be. ${ }^{89}$ However, publicly available information about collateral joint enterprise liability is patchy and $a d h o c^{90}$ and many who are convicted through collateral joint enterprise perceive the law only after being convicted. And those who are convicted through extended joint criminal enterprise liability, especially for murder, often refuse to accept that the label and sentence they have received justly reflect their wrongdoing. ${ }^{91}$ Consequently, the deterrence effect of unfair punishment seems not as effective as the English courts hold.

With regard to the third pragmatic consideration that extended joint criminal enterprise liability will alleviate the prosecution from unrealisable burden of proof, ${ }^{92}$ it is submitted that principles of justice should not be abandoned in order to get easy convictions. The extended joint criminal enterprise liability has the advantage that if the Crown cannot prove which gang member perpetrated the collateral crime it can convict them all, if it can prove it had to be one of them, ${ }^{93}$ and that the Crown need not prove intention on D's part but mere recklessness would be enough. ${ }^{94}$ When the state finds it difficult to prove criminal charges using personal liability offences it may find it easier to use mechanisms that deem all present

\footnotetext{
${ }^{89}$ See Paul H. Robinson, "Does Criminal Law Deter? A Behavioural Science Investigation" (2004) 24(2) Oxford Journal of Legal Studies 173, 173. See also Paul H. Robinson et al, "Empirical Desert, Individual Prevention, and Limiting Retributivism: A Reply" (2014) 17(2) New Criminal Law Review 312.

${ }^{90}$ Justice Committee, "Joint Enterprise: Follow Up" (Fourth Report of Session 2014-15, House of Commons, 2014$) 10$.

${ }^{91}$ Wilson and Ormerod, n. 17 above, 21.

${ }^{92} R$ v Powell and English [1999] 1 AC 1, 4; House of Commons, Joint Enterprise report n. 1 above, 16.

${ }^{93}$ See Glanville Williams, "Which of You Did It?" (1989) 52 The Modern Law Review 179.

${ }^{94} R v$ Powell and English [1999] 1 AC 1; $R v A B C D$ [2011] QB 841.
} 
equally liable, but this sort of collective liability is unjust. It is also counter-utilitarian. ${ }^{95}$ Extended joint criminal enterprise liability has caused serious difficulties for juries due to its complexity and lack of clarity. ${ }^{96}$ It is reported that collateral joint enterprise liability has been the subject of a high number of appeals in recent years. ${ }^{97}$ Most of the difficulties have to do with the complexity of the rules, not with proving the facts or proving who did it. There are many cases where it is difficult for the prosecution to prove beyond reasonable doubt the required mental elements of a crime, but this does not mean the fault element should be supplanted with one that is easier to prove- or with strict collective liability for the entire group. There is nothing to be gained by obtaining easy convictions at the cost of circumventing the core principles of justice. Failures of justice due to difficulties of proof in multi-party cases should be addressed directly, rather than by creating fictitious rule.

\section{The Extreme Unfairness and Injustice of Double Constructive Liability Manifested in Extended Joint Criminal Enterprise Doctrine}

It has been argued above that the doctrine of extended joint criminal enterprise manifests a form of double constructive liability, which cannot be justified normatively. Now the extreme unfairness and injustice of such a double constructive liability will be expounded.

Stand complicity is a form of constructive liability in that an accessory's full liability for the target crime is constructed on his or her participation in the commission of that crime. His or her assisting/encouraging the commission of the target crime is constructed as perpetration of

\footnotetext{
${ }^{95}$ Miceli and Segerson, n. 88 above.

${ }^{96}$ House of Commons, Joint Enterprise report n. 1 above, 10.

${ }^{97}$ Justice Committee, "Joint Enterprise: Follow Up", n. 90 above, 16 asserting that 22 per cent of all convictions appealed to the Court of Appeal in 2013 had an element of joint enterprise, which is regarded as a terrifying statistic.
} 
that crime, and his or her mens rea in assisting or encouraging its commission is constructed as requisite mens rea of that crime. However, assisting/encouraging is normatively different from perpetration; the latter causes the prohibited harm in the target crime but the former merely contributes to the occurrence of that prohibited harm in a remote way. The causation requirement in criminal liability links the perpetrator's guilt and punishment to the prohibited harm and serves as an essential tool for measuring the perpetrator's moral desert and determining what will be proportionate punishment for the harm caused. "Natural events occur in consequence of some antecedent events" and are governed by the laws of nature. ${ }^{99}$ It is the logic of causal laws that given certain conditions it can be said with certainty that certain result will occur or not. But human actions are wild cards and the law of nature governs natural events cannot be applied to human beings. Humans act as they choose unless they are coerced, deceived or fettered so that they cannot freely choose to do what they desire. Complicity makes a person liable for the crime another independent and autonomous individual has committed, the normal causation rules in perpetration liability do not apply in this context. ${ }^{100}$

Complicity does not require but-for cause, a possibility of but-for relationship would suffice. ${ }^{101}$ Even if in some cases it can be argued that but for the accessory's assisting/encouraging the prohibited harm in the target crime would not have occurred as and when it did, the legal cause test can never be met. The perpetrator's free, deliberate and voluntary perpetration has broken any chain of causation between the accessory's conduct

\footnotetext{
${ }^{98}$ See Joshua Dressler, "Reforming Complicity Law: Trivial Assistance as a Lesser Offence?" (2008) 5(2) Ohio State Journal of Criminal Law 427, 436; Sanford H. Kadish, "Complicity, Cause and Blame: A Study in the Interpretation of Doctrine" (1985) 73(2) California Law Review 323, 330.

${ }^{99}$ Ibid, Kadish.

${ }^{100}$ When I refer to causation I have in mind the double-prong test used in perpetration liability, that is, the but-for cause and the legal cause for imputing causation. Causation is used in its core sense in this article as it is used in perpetration liability.

${ }^{101}$ Kadish, n. 98 above, 360.
} 
and the prohibited harm in the target crime. The thumb rule of novus actus interveniens provides that where a person knowingly intervenes and therefore brings about the prohibited harm, without being fettered, constrained or deceived by another, his intervening act will absolve the previous actor of criminal liability. ${ }^{102}$ Where the so called perpetrator is not making a free, deliberate and voluntary choice to do the crime, the innocent agency doctrine will apply and the person who deceives, coerces or compels will be liable for the crime as real perpetrator. Some scholars argue that accessories can cause through the conduct of the perpetrator, ${ }^{103}$ but they are using the word "causation" "in a special or technical sense that need not conform to our ordinary use of the word, while still trading on what we normally

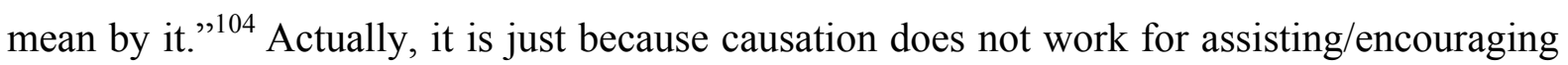
that complicity came into being working as soft clay around the contours of perpetration liability. ${ }^{105}$ Complicity is marked out from paradigm perpetration liability in that the basis of complicity is not what the defendant has done but what the perpetrator has done. ${ }^{106}$ Therefore, assisting/encouraging is normatively different from perpetration.

Furthermore, assisting/encouraging is less harmful and less dangerous than perpetration in that the harmfulness of assistance/encouragement is contingent on the perpetrator's making an independent and autonomous choice to commit the target crime. Assisters/encouragers stand one step further from the prohibited harm because the harm is initiated by the perpetrator. Therefore, participation is a remote harm, as compared to perpetration, which the

\footnotetext{
$\overline{{ }^{102} R v \text { Kennedy (No.2) [2008] } 1 \text { AC 269 }}, 276 ; R v$ Gnango [2012] 1 AC 827, 867; Burns $v R$ [2011] NWSCCA 56; H. L. A. Hart and Tony Honoré, Causation in the Law (Oxford: Oxford University Press, 2002) 326; Baker, n. 3 above, 218; see also Simester et al, Criminal Law: Theory and Doctrine (Oxford: Hart Publishing, 6th ed, 2016) 96-98; Glanville Williams, "Finis for Novus Actus?" (1989) 48 Cambridge Law Journal 391, 398.

${ }^{103}$ See generally Sullivan, n. 17 above; John Gardner, "Complicity and Causality" (2007) 1 Criminal Law and Philosophy 127, 141; Michael S. Moore, Causation and Responsibility (New York: Oxford University Press, 2010) 232.

${ }^{104}$ Daniel Yeager, "Helping, Doing, and the Grammar of Complicity" (1996) 15(1) Criminal Justice Ethics 25, 29.

${ }^{105}$ Moore, n. 103 above, 232.

${ }^{106}$ William Wilson, Central Issues in Criminal Theory (Oxford: Hart Publishing, 2002) 195.
} 
criminal law seeks to prevent. When we are speaking of remote harm, it is not the literal spatio-temporal remoteness that matters; rather, it is the remoteness in a sense that such harm involves certain kinds of contingencies that matters. ${ }^{107}$ The harmfulness of perpetration is certain because it initiates the prohibited harm; the harmfulness of participation is not certain in itself as it is contingent on the perpetrator's independent choice. It is in this sense that assisting or encouraging is less harmful than perpetration. Moreover, assisting/encouraging is less dangerous than perpetration because accessories do not have control over the occurrence of the prohibited harm and they do not have the fortitude or resolve to commit the crime by their own hands. As moral agents, we have the capacity to choose to violate the law or not. ${ }^{108}$ The perpetrator is made fully liable because he or she has unjustifiably caused certain change in certain circumstances in this world while he or she has full control over the direct action that produces the harm. But assisters/encouragers not only have no control over the eventual prohibited harm, but also have no control over the conduct which causes the eventual harm. They leave it all to the decision of the perpetrator. Assisters/encouragers may never commit the crime if they are going to use their own hands to do the dirty work. An intention to assist/encourage the commission of the target crime is different from the mens rea of that crime. It is easier to imagine killing someone than actually doing it. Did Shakespeare's Lady Macbeth have the same mental wherewithal as Macbeth? She certainly had the wherewithal to encourage, but perhaps not to perpetrate. There is a difference in the mental psychology and hence dangerousness of a remote party to a direct act of killing. It takes more nerve to perpetrate than to assist or encourage from one step removed. Treating an accessory the same as a perpetrator is a form of constructive liability because he or she has neither actus reus nor mens rea of the target crime.

\footnotetext{
${ }^{107}$ See Andrew von Hirsch, "Extending the Harm Principle: 'Remote' Harms and Fair Imputation" in A. P. Simester and A. T. H. Smith (eds), Harm and Culpability (Oxford: Clarendon Press, 1996) 263.

${ }^{108}$ See Larry Alexander et al, Crime and Culpability: A Theory of Criminal Law (New York: Cambridge University Press, 2011) 196.
} 
In the context of extended joint criminal enterprise liability there is a double layer of constructive liability. D's participation in the underlying crime is constructed as actual assistance/encouragement in the collateral crime, and D's foresight of the commission of the collateral crime is constructed as sufficient mens rea for complicity, which requires an intention to assist/encourage knowing all the essential matters of the target crime. ${ }^{109}$ Such fictitiously constructed actus reus and mens rea for standard complicity regarding the collateral crime is further constructed as the requisite actus reus and mens rea of the collateral crime. Assisting/encouraging the collateral crime is less harmful than perpetration the collateral crime, and risking the collateral crime is less harmful than assisting or encouraging the collateral crime; therefore, risking the collateral crime in a joint criminal enterprise is much less harmful than perpetration the collateral crime. Labelling and punishing assistance/encouragement and perpetration in the same way is unfair and unjust as it has infringed the principle of fair labelling ${ }^{110}$ and the principle of proportionate punishment. ${ }^{111}$ Extended joint criminal enterprise liability adds even more unfairness and

\footnotetext{
109 The English law of complicity post-Jogee requires an accessory to have an intention with regard to all the elements of the target crime. The pre-Jogee law however allowed foresight of the commission of the target crime as sufficient mens rea for complicity. $R$ v Bryce [2004] 2 Cr App R35; $R$ v Luffman [2008] EWCA Crim 1739. Australia and Hong Kong have not changed their laws of complicity requiring an intention to assist or encourage knowing the essential matters of the crime. Giorgianni v The Queen [1985]156 CLR 473; Rv Lao Chi-Kin [1988] HKLR 282. HKSAR v Chu Wai San and Others [2008] HKLRD 18. As I am mainly focusing on the extended joint criminal enterprise liability which is still existing in Australia and Hong Kong, I will adopt the mens rea requirement for complicity in these two jurisdictions.

${ }^{110}$ Glanville Williams, "Convictions and Fair Labelling" (1983) 41(1) Cambridge Law Journal 85; Joel Feinberg, Doing and Deserving: Essays in the Theory of Responsibility (Princeton: Princeton University Press, 1970) Chapter 5, "The Expressive Function of Punishment"; Douglas Husak, "The Criminal Law as Last Resort" (2004) 24(2) Oxford Journal of Legal Studies 207; Bernard E. Harcourt, "Joel Feinberg on Crime and Punishment: Exploring the Relationship between The Moral Limits of Criminal Law and The Expressive Function of Punishment" (2001) 5 Buffalo Criminal Law Review 145.

${ }^{111}$ Douglas Husak, "Retributivism, Proportionality and the Challenge of the Drug Court Movement" in Michael Tonry (ed), Retributivism Has a Past: Has It a Future? (New York: Oxford University Press, 2011); Hirsch, n. 55 above; John Gardner, "Crime: in Proportion and in Perspective" in Andrew Ashworth and Martin Wasik (eds), Fundamentals of Sentencing Theory (Oxford: Clarendon Press, 1998); R. A. Duff and Andrew Von Hirsch, "Responsibility, Retribution and the "Voluntary": A Response to Williams " (1997) 56(1) Cambridge Law Journal 103.
} 
injustice by allowing a person to be labelled and punished for a much worse wrongdoing when he or she never perpetrated that wrongdoing, nor did he or she ever assist/encourage that wrongdoing.

Retributive justice requires fair labelling and proportionate punishment in criminal law. Fair labelling is a principle of justice immune from challenge ${ }^{112}$ though it is not explicitly adopted in some jurisdictions. The principle of fair labelling is widely deployed in many areas of criminal law, ${ }^{113}$ such as distinguishing different kinds of homicide ${ }^{114}$ distinguishing theft from obtaining property by deception ${ }^{115}$ and distinguishing rape from other sexual offences. ${ }^{116}$ It is essential to the communication function of criminal law that crime labels should communicate different degrees of condemnation of different types of conduct, and that crime labels should be created to reflect the degree of harm-doing and personal culpability. ${ }^{117}$ Only when the crime label fairly represents harm-doing and personal culpability would it communicate to the public, legal professionals as well as the defendant effectively and therefore reinforce legal compliance. Proportionate punishment is in the core of retributive justice $^{118}$ requiring the severity of punishment should be proportionate to the seriousness of

\footnotetext{
112 Williams, n. 110 above, 85-86.

113 James Chalmers and Fiona Leverick, "Fair Labelling in Criminal Law" (2008) 71(2) The Modern Law Review 217, 219220.

${ }^{114}$ C. M. V. Clarkson, "Context and Culpability in Involuntary Manslaughter: Principle or Instinct" in Andrew Ashworth and Barry Mitchell (eds), Rethinking English Homicide Law (Oxford: Oxford University Press, 2000); Victor Tadros, "The Homicide Ladder" (2006) 69 Modern Law Review 601.

115 C. M. V. Clarkson, "Theft and Fair Labelling" (1993) 56 Modern Law Review 554; P. R. Glazebrook, "Thief or Swindler: Who Cares?" (1991) 50 Cambridge Law Journal 389; P. R. Glazebrook, "Revising the Theft Acts" (1993) 52 Cambridge Law Journal 191; Stephen Shute and Jeremy Horder, "Thieving and Deceiving: What's the Difference?" (1993) 56 Modern Law Review 548

${ }^{116}$ Victor Tadros, "The Distinctiveness of Domestic Abuse: A Freedom-Based Account" in R. A. Duff and Stuart Green (eds), Defining Crimes: Essays on the Special Part of the Criminal Law (Oxford: Oxford University Press, 2005)

${ }^{117}$ Chalmers and Leverick, n. 113 above, 226; Clarkson, n. 114 above.

${ }^{118}$ Husak, n. 111 above, 220; Douglas Husak, ""Broad" Culpability and Retributivist Dream" (2011-2012) 9(2) Ohio State Journal of Criminal Law 449, 453.
} 
the criminal conduct of which the defendant is convicted. ${ }^{119}$ Punishing the offender for his or her conduct indicates community's disapproval and reprobation towards that conduct. It is just because punishment visits blame that it should be proportionate with the offender's blameworthiness. Disproportionate punishment is unfair and unjust because it purports to condemn the defendant for what he or she has done yet visit more or less censure on him or her than the blameworthiness his or her conduct would warrant. ${ }^{120}$

According to the principle of fair labelling, not only the type of wrongdoing should be distinguished with different crime labels but also the degree of wrongdoing should be represented in the crime labels. ${ }^{121}$ Take the typical robbery-murder case for example, a participant in a joint enterprise of robbery risks the collateral crime murder being perpetrated by his confederates by remaining in the enterprise after foreseeing the risk of murder being committed, but he has neither assisted/encouraged the commission of murder nor perpetrated the actus reus of murder. Labelling risk-taking as assisting/encouraging and then further labelling such fictitiously constructed assisting/encouraging as perpetration goes against the principle of fair labelling, because the type and gravity of the participant's harm-doing (risktaking) is not correctly represented by the crime label (murder). Moreover, labelling the participant in robbery as a murderer does not reflect his personal culpability (mens rea) either. The mens rea represented by murder is an intention to kill or cause grievous bodily harm, but the participant merely has a foresight with regard to the perpetrator's unlawful killing.

\footnotetext{
${ }^{119}$ Hirsch, n. 55 above, 29; Douglas Husak, "Desert, Proportionality, and the Seriousness of Drug Offences" in Andrew Ashworth and Martin Wasik (eds), Andrew Von Hirsch and Andrew Ashworth, Proportionate Sentencing: Exploring the Principles (Oxford: Oxford University Press, 2005) 131-132; Gardner, n. 111 above, 39; Duff and Hirsch, n. 111 above, 105. ${ }^{120}$ Ibid, Hirsch and Ashworth, 134.

${ }^{121}$ Barry Mitchell, "Multiple Wrongdoing and Offence Structure: A Plea for Consistency and Fair Labelling" (2001) 64(3) Modern Law Review 393, 398.
} 
The principle of proportionate punishment requires the severity of punishment should be proportionate to the seriousness of the criminal conduct of which the defendant is convicted. ${ }^{122}$ Serious wrongdoing should not be punished leniently and trivial wrongdoing should not be punished severely. The punishment given to a participator in an extended joint criminal enterprise case does not match the defendant's harm-doing which is mere risk-taking rather than perpetration. Take the robbery-murder case for instance again, taking a risk that $\mathrm{P}$ might kill is much less harmful than the conduct of killing and the D's foresight that P might commit murder is less culpable than an intention to kill or cause grievous bodily harm by his own hands. Punishing D's risk-taking with punishment designed for unlawful killing with the intent to kill or cause grievous bodily harm is extremely disproportionate. If people are to be held equally liable, there should be correspondence in their personal culpability (the specific mens rea they hold) and the harmfulness of their wrongdoing. Certainly, there is no such correspondence in the context of extended joint criminal enterprise liability.

Punishing assister/encourager the same as perpetrator has ignored the normative difference between assisting/encouraging and perpetration and therefore is unjust and unfair. Such unfairness and injustice is doubled in the context of extended joint criminal enterprise liability when the defendant is constructively made liable for the collateral crime on the legal fiction that by joining in the underlying crime he or she has also given assistance/encouragement to the collateral crime had he or she foreseen the collateral crime as incidental. It is the severe infringement of principles of fair labelling and proportionate punishment that we have to abrogate this double constructive liability. If any criminalisation

\footnotetext{
${ }^{122}$ Hirsch, n. 55 above, 29; Husak, n. 119 above, 189; Hirsch and Ashworth, n. 119 above, 131-132; Andrew Von Hirsch, "Proportionality in the Philosophy of Punishment" (1992) 16 Crime \& Just. 55.
} 
is needed to deal with such defendants, it should be done in a way to correctly reflect the defendants' harm-doing and personal culpability.

\section{Proposing a New Lesser Offence of Risking Another's Collateral Offending}

It has been argued above that extended joint enterprise liability should be abolished, but what options do we have if that abolition is done? English law has inchoate assisting/encouraging offences enacted in Part 2 of the Serious Crime Act 2007. Would such offences be possible solutions to deal with cases covered by the current extended joint criminal enterprise liability? The answer is negative. Though these inchoate offences punish offenders based on individual liability rather than derivative liability under complicity, they do require the defendant has done a conduct that is capable of assisting/encouraging the commission of the target crime. ${ }^{123}$ But in an extended joint criminal enterprise case, the defendant did not do anything that was capable of assisting/encouraging the perpetrator to commit the collateral offence. What he or she did was participating with the perpetrator in the underlying crime, but this did not necessarily encourage the perpetrator to commit any crime that was foreseen as a possible incident of the joint enterprise to do the underlying crime. Moreover, the defendant's foresight of the collateral crime cannot satisfy the mens rea requirements of any of the inchoate assisting/encouraging offences in the 2007 Act, which require either an intention or oblique intention to assist/encourage the perpetrator's crime. ${ }^{124}$

\footnotetext{
${ }^{123}$ Serious Crime Act 2007 (UK), ss.44-46; $R$ v Blackshaw [2011] EWCA Crim 2312 at [54].

${ }^{124}$ Dennis Baker, "Conceptualizing Inchoate Complicity: The Normative and Doctrinal Case for Lesser Offences as an Alternative to Complicity Liability” (2016) 25 Southern California Interdisciplinary Law Journal 503, 517-520; Graham Virgo, "R v Sadique: Making Sense of Section 46 of the Serious Crime Act 2007" (2013) 7 Archbold Review 4, 5.
} 
However, the judicial practice shows an inclination, however, to punish people who participated in an underlying crime with the foresight of a collateral crime being committed, rather than to let them go free. This is interestingly shown in the case of $R v$ Jogee where their Lordships provided manslaughter as an alternative to convict the defendant after having abolished the extended joint enterprise doctrine which would make the defendant liable for murder. ${ }^{125}$ But this approach is far from satisfactory. Their Lordships seem to have conflated constructive manslaughter and complicity by making this recommendation. If $\mathrm{D}$ assisted/encouraged $\mathrm{P}$ to do an unlawful act against $\mathrm{V}$, say, inflicting moderate bodily harm short of grievous bodily harm, and $\mathrm{P}$ did as assisted/encouraged causing an unintended consequence of death, this would render $\mathrm{P}$ be liable for manslaughter and $\mathrm{D}$ be liable for manslaughter through derivative complicity. In such a situation there was only one crime committed by $\mathrm{P}$, which was constructive manslaughter and it is not problematic to make $\mathrm{D}$ liable for manslaughter through derivative complicity. D's criminal liability for manslaughter hinges on his assisting/encouraging P to do an unlawful act which causes death unintendedly. However, cases like Jogee are different in that death of the victim was caused by P's deliberate and autonomous choice to commit murder. Here death was an unintended consequence to D, but it was the purposive, rather than unintended, consequence on P's part. In such cases death was caused by the independent murderous act of the perpetrator which was not assisted/encouraged by $\mathrm{D}$, rather than caused by the act $\mathrm{D}$ intended to assist/encourage. ${ }^{126}$ It is odd to say that D had assisted/encouraged constructive manslaughter while P had committed murder. ${ }^{127}$ Their Lordships had made a great contribution by restraining the mens rea element of complicity to intention only; however, I would say, with

\footnotetext{
${ }^{125} R$ v Jogee [2016] UKSC 8 at [106].

${ }^{126}$ Simester, n. 11 above, 87.

${ }^{127}$ Baker, n. 11 above, 54.
} 
great respect, they had not done equally well, unfortunately, with regard to the defendant's liability for the perpetrator's collateral offending.

It is submitted that it is a wrong per se to risk another person's perpetration a collateral crime by joining an underlying crime foreseeing that his or her confederate of the underlying crime might perpetrate that collateral crime. The foresight and association elements mean it is not a problem of moral bad luck or moral good luck. ${ }^{128}$ The participator's liability for the collateral crime is not a case of moral bad luck per se, because he or she had foreseen the risk of the collateral crime being committed but nonetheless made a choice to join the underlying crime to risk the occurrence of that collateral crime. If the defendant did not join the joint underlying criminal enterprise such as a bank robbery or gang violence, the perpetrator might not have been willing to perpetrate the underlying crime on his or her own and thus the risk of the perpetrator perpetration a collateral crime would have been reduced. It is their joint enterprise that put the perpetrator in a position where he or she might commit the collateral offence. Such risk-taking does not warrant full criminal liability on D's part for the collateral crime committed by the perpetrator, but it is enough to justify some sort of criminal liability. The joint enterprise of the underlying offence was the background of the collateral offending and D acted positively in setting this background. There is public interest in criminalise such culpable risk creation. ${ }^{129} \mathrm{~A}$ person who continues his or her participation in a criminal enterprise to do an underlying crime after having foreseen the possibility of a collateral crime, is taking an unjustifiable risk and thus should take criminal liability for his or her

\footnotetext{
${ }^{128}$ Luck theory is discussed in Kimberly D. Kessler, "The Role of Luck in the Criminal Law" (1994) 142(6) University of Pennsylvania Law Review 2183.

${ }^{129}$ G. R. Sullivan, "Participating in Crime: Law Com No. 305: Joint Criminal Ventures" (2008) 1 Criminal Law Review 19, 30.
} 
culpable risk-taking. Such criminalisation could be done by having specific offence ${ }^{130}$ rather than through double constructive liability.

Such a risk-taking rationale would encounter problems if it is used to justify labelling and punishing the defendant in the same way as the perpetrator for the collateral crime because the wrong-doing in risking another's crime is quite different in nature and degree from perpetration the actus reus of that crime with the requisite mens rea. However, this rationale could work perfectly well for my proposed new lesser offence of risking another's collateral offending because the core wrong in this new offence is the defendant's culpable risk-taking. The crime label correctly reflects the defendant's harm-doing (risk-taking) and his or her personal culpability (recklessness). The conduct element of this new lesser offence would be that $\mathrm{D}$ continued his or her participation in the enterprise of doing an underlying crime foreseeing the commission of the collateral offence as a possible incident of the joint enterprise. It is not his or her mere participation in the underlying crime that matters; rather, it is his or her continued participation after he or she had foreseen the possibility of the collateral offence being committed that matters. The emphasis is on his or her continual participation in circumstances where the risk of the collateral offence was very apparent. By continuing his or her participation with that foresight, D manifested sufficient culpability and his or her participation in these circumstances warranted some form of punishment.

It is proposed that this offence is a generic offence that could be applied to any sort of crime. It is also proposed that this offence can only be committed if $\mathrm{P}$ has actually committed the collateral crime. The mens rea element for this new offence is subjective recklessness. As long as $\mathrm{D}$ foresaw that there was a possibility that $\mathrm{P}$ might commit the collateral offence it

\footnotetext{
${ }^{130}$ Simester, n. 11 above, 82.
} 
would suffice. By continuing one's participation in a criminal enterprise after having realised he or she was risking other collateral crimes the defendant was apparently running that risk unreasonably, so this means the defendant would satisfy the recklessness test when he or she had that foresight. Where $\mathrm{D}$ did not foresee that $\mathrm{P}$ might commit a further offence in the course of the underlying crime he or she should not be liable for this new offence, even if an ordinary person could have foreseen the commission of that further offence. The fundamentally different act rule will still have its place in this new offence because the defendant should only be responsible for what he or she subjectively risked. If the collateral offending by the perpetrator was fundamentally different from what the defendant had foreseen or contemplated, the defendant should not be liable for that offence because he or she did not risk it with awareness.

\section{Conclusion}

This paper seeks to provide a normative case for abolishing the doctrine of extended joint enterprise and replacing it with a new lesser offence of risking another's collateral offending. Treating assisting/encouraging in the same way as perpetration infringes the basic criminal law principles of fair labelling and proportionate punishment and therefore is unfair and unjust. And such unfairness and injustice is doubled in the context of extended joint criminal enterprise where the defendant's full liability for the collateral crime is constructed twice, out of his or her participation in the underlying crime. English law in the high profile case $R v$ Jogee has reinterpreted the mental element for complicity liability requiring nothing short of intention and denied any independent extended joint enterprise doctrine. But their Lordships' making the defendant liable for manslaughter for the perpetrator's collateral offending of murder does not provide us a satisfactory solution. Courts in some other jurisdictions, 
however, refuse to follow $R v$ Jogee and retain extended joint criminal enterprise doctrine as valid law. It is submitted that proper law reform is needed so as to meet the requirements of fair labelling and proportionate punishment. A new lesser offence of risking another's collateral offending, based on a risk-taking rationale, is proposed. A defendant caught by this new offence will not be held fully liable for a crime that he or she did not perpetrate or assisted/encouraged its perpetration, rather, he or she will be made liable for running an unreasonable risk of a collateral offending by continuing his or her participation in a criminal enterprise to do un underlying crime. Such criminalisation would allow the defendant to be labelled and punished fairly in accordance with his or her own harm-doing and personal culpability. 